\title{
BRPKM
}

Buletin Riset Psikologi dan Kesehatan Mental

http://e-journal.unair.ac.id/index.php/BRPKM

e-ISSN: 2776-1851

ARTIKEL PENELITIAN

\section{Pengaruh Perceived Supervisor Support dan Fear of COVID-19 terhadap Job Burnout pada Frontline Service Employee di masa Pandemi COVID-19}

\author{
SHEILA NOOR MAULIDA \& HERISON PANDAPOTAN PURBA* \\ Fakultas Psikologi Universitas Airlangga
}

\begin{abstract}
ABSTRAK
Penelitian ini bertujuan untuk menguji pengaruh perceived supervisor support dan fear of COVID-19 terhadap job burnout pada FLE di masa pandemi COVID-19. Penelitian ini melibatkan 118 responden pada rentang usia 19-42 tahun. Penelitian ini menggunakan uji regresi dengan multiple regression sebagai teknik analisis data dengan bantuan program Jamovi 1.6.23. Hasil analisis pada penelitian ini memiliki koefisien regresi $\left(\mathrm{R}^{2}\right)$ sebesar 0.345 dengan nilai signifikansi $(\mathrm{p})$ sebesar $<.001$. Hasil ini memperlihatkan bahwa PSS dan FCV-19 secara bersamaan dapat menjelaskan variasi job burnout sebesar 34.5\%. Nilai estimate variabel PSS memiliki nilai negatif dimana setiap kenaikan 1 skor PSS akan menurunkan job burnout sebesar 0,495. Sedangkan nilai estimate variabel FCV-19 memiliki nilai positif dimana setiap kenaikan 1 skor FCV-19 akan menaikkan job burnout sebesar 0,569.
\end{abstract}

Kata kunci: fear of COVID-19, job burnout, perceived supervisor support

\section{ABSTRACT}

This study purposively verifies the effect of perceived supervisor support and fear of COVID-19 towards job burnout. The study involves 118 respondents in age of 19-42. This study uses the regression with multiple regression using Jamovi 1.6.23 program. The results of the analysis in this study have a regression coefficient (R2) of 0.345 with a significance value (p) of $<.001$. These results announce the PSS and FCV-19 can simultaneously explain the $34.5 \%$ variation in job burnout. The estimated value of the two variables has a positive sign, which means that every 1 increase in PSS score will decrease job burnout by 0,495. Furthermore, an increase of $1 \mathrm{FCV}-19$ score will increase job burnout by 0,569.

Keywords: fear of COVID-19, job burnout, perceived supervisor support

Buletin Penelitian Psikologi dan Kesehatan Mental (BRPKM), 2021, Vol. 1(2), 1227-1236

*Alamat korespondensi: Fakultas Psikologi Universitas Airlangga, Kampus B Universitas Airlangga Jalan

Airlangga 4-6 Surabaya 60286. Surel: herison.purba@psikologi.unair.ac.id

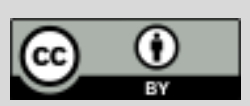

Naskah ini merupakan naskah dengan akses terbuka dibawah ketentuan the Creative Common Attribution License (CC-BY-4.0) (http://creativecommons.org/licenses/by/4.0), sehingga penggunaan, distribusi, reproduksi dalam media apapun atas artikel ini tidak dibatasi, selama sumber aslinya disitir dengan baik. 


\section{PEN D A H U L U A N}

Hingga kini pandemi yang diakibatkan oleh penyebaran corona virus disease 19 atau COVID-19 masih belum mereda. Virus ini pertama kali ditemukan di Wuhan, China dan menyebar dengan cepat. Pada awal penyebarannya, dalam waktu kurang dari 3 bulan, virus ini sudah menginfeksi sebanyak 126.000 orang di 123 negara di seluruh dunia. Maka dari itu, WHO secara resmi menyatakan penyebaran virus COVID-19 sebagai pandemi global pada bulan Maret tahun 2020 kemarin. Wabah COVID-19 adalah krisis dunia yang menular dengan kejam, bergerak cepat, dan mematikan (Berry dkk., 2020). Dalam waktu yang singkat, pandemi COVID-19 ini menyebabkan banyak perubahan disetiap aspek kehidupan manusia. Pada sektor perekonomian, pandemi COVID-19 telah menjatuhkan ekonomi global ke dalam kontraksi yang parah. Dalam waktu yang singkat ini, pandemi COVID-19 juga telah mengejutkan pasar global dan mengubah cara konsumen, karyawan, dan organisasi berinteraksi.

Sementara banyak dari perhatian media dan akademis hanya difokuskan pada petugas kesehatan (Adams \& Walls, 2020), Frontline Service Employee atau FLE lain yang beroperasi di garis depan selain dari petugas kesehatan juga terdampak (Berry \& Stuart, 2021). Ketika pandemi ini beberapa perusahaan tidak menerapkan system WFH sama sekali yang artinya di tengah bahaya transmisi wabah COVID-19, perusahaan tersebut masih terus beroperasi sebagaimana biasanya (Poppy, 2020). Mereka adalah pekerja yang dalam kesehariannya bertatap muka langsung dengan dengan customer. Seperti contoh, bidang perbankan (teller, customer service), ekspedisi barang (kurir), retail, pangan (pegawai supermarket, pelayan restoran) dan lainnya. Demi menyanggupi kebutuhan sehari-hari, para karyawan tersebut harus bersedia bekerja dari kantor atau WFO dan menjaminkan nyawa mereka di tengah meningkatnya pandemi berbahaya ini (Poppy, 2020). Secara keseluruhan, pekerjaan FLE ini termasuk kedalam pekerjaan yang rentan dengan burnout karena mereka sering menghadapi situasi yang menyebabkan stress dan banyaknya tuntutan di lokasi kerja, termasuk beban kerja yang berat, stres peran, disonansi emosional, dan jam kerja yang tinggi.

Pada penelitian yang dilakukan oleh Voorhees dkk. (2020) di AS, beberapa FLE melaporkan mereka mengalami peningkatan stres dalam kehidupan kerja mereka saat pandemi COVID-19 ini. Mereka juga mengungkapkan keprihatinan tentang terbatasnya rasa kasih sayang yang ditunjukkan oleh konsumen dan supervisor. Seperti contoh, beberapa konsumen mengabaikan persyaratan tentang social distancing dan FLE kesulitan untuk mengatur perilaku menyimpang ini. Dengan peningkatan stress pada kehidupan kerja dan beban kerja yang semakin tinggi FLE semakin rentan terhadap burnout.

Wawancara yang dilakukan oleh Guardian Magazine pada beberapa frontline workers di AS melaporkan hal yang sama. Pada hasil wawancara ini diketahui FLE mengalami burnout yang disebabkan oleh peningkatan beban kerja, kekurangan staf, stres yang terkait dengan ketakutan akan virus corona dan perjuangan dalam menegakkan jarak sosial dan protokol keselamatan. "Ini adalah mimpi buruk. Ini melelahkan, secara mental, emosional, dan fisik." ujar salah satu narasumber. Saat ini, ketika pembatasan COVID-19 telah dicabut di sebagian besar AS dan ekonomi telah hidup kembali, banyak FLE masih takut akan keselamatan mereka dan gusar dengan kondisi kerja mereka. Narasumber lain menyatakan, selama pandemi dia terus-menerus khawatir sakit, anggota keluarganya jatuh sakit, dan di saat yang bersamaan tetap berjuang untuk menangani customer yang menolak mengikuti protokol keselamatan virus corona seperti penggunaan masker dan social distancing (Sainato, 2020).

Di Indonesia sendiri, masyarakat (secara keseluruhan) merasa terancam oleh virus tersebut dan merasa bahwa tanggapan pemerintah yang terlambat membuat mereka rentan terhadap pandemi (Almuttaqi, 2020). Ancaman kematian ada di mana-mana dan di waktu bersamaan, kesiapsiagaan untuk menghadapi pandemi masih kurang (Djalante dkk., 2020; Gudi \& Tiwari, 2020) juga pelayanan kesehatan yang kurang (Setiati \& Azwar, 2020), dan kebijakan social distancing dan lockdown memiliki 
mobilitas yang terbatas (Satya, 2020). Hal ini tampaknya telah mengakibatkan berbagai konsekuensi psikologis, termasuk ketakutan dan stigma (Lin, 2020). Ketakutan dan kepanikan tentang COVID-19 dapat menyebabkan pengalaman stigmatisasi dan pengucilan sosial dari pasien yang dikonfirmasi, penyintas, keluarga mereka, dan orang lain yang terkait dengan penyakit yang dapat menyebabkan peningkatan risiko kesehatan mental seperti gangguan penyesuaian dan depresi (Chen dkk., 2020). Selain itu, orang yang tidak terinfeksi melaporkan bahwa mereka takut berhubungan dengan orang yang terinfeksi COVID-19 (Lin, 2020). Tingkat ketakutan yang tinggi terhadap COVID-19 juga dapat menyebabkan pemikiran yang tidak rasional dan tidak jelas (Ahorsu dkk., 2020). Situasi pandemi COVID-19 saat ini yang kembali mengkhawatirkan dapat digolongkan sebagai kondisi lingkungan yang tidak mendukung FLE dalam bekerja.

Greenberg (2003) menyatakan bahwa, burnout dapat terjadi karena adanya kondisi lingkungan yang kurang baik atau tidak mendukung. Seperti contoh, pada riset yang dilakukan oleh Edelweiss (2021) pada karyawan bank di Jakarta, ditemukan bahwa karyawan dapat mengalami burnout di tempat kerja dikarenakan mereka harus beradaptasi dengan situasi yang baru. Contoh perubahannya adalah aktivitas fisik yang harus dibatasi (berjabat tangan, berpelukkan, menjaga jarak dengan orang lain, dan lain-lain). Edelweiss (2021) juga menyatakan bahwa bukan hanya beban kerja yang tinggi yang dapat memengaruhi burnout pada karyawan, namun kewajiban untuk bertemu client/customer dimasa pandemi juga menambah tingkat kekhawatiran pada karyawan bank. Hal ini, dikarenakan besarnya jumlah karyawan bank yang tertular COVID-19 melalui customer yang mereka layani (Edelweiss, 2021). Walaupun begitu mereka juga harus bersikap profesional untuk melayani customer dan mengerjakan pekerjaan mereka ditengah situasi yang sebenarnya tidak mendukung untuk tetap bekerja di kantor. Dari hasil wawancara pada penelitian ini dapat diketahui bahwa pekerja bank memiliki tanggung jawab lebih untuk tetap bekerja di kantor, dan tidak dapat bekerja dari rumah atau WFH. Oleh karena itu, dapat disimpulkan, bahwa tingkat burnout pada karyawan bank terbilang tinggi. Tidak hanya karyawan bank yang mengerjakan restrukturisasi kredit, namun karyawan yang mengerjakan layanan lain juga dapat mengalami burnout selama masa pandemi ini (Edelweiss, 2021).

Dalam menjelaskan job burnout, disebutkan bahwa perceived supervisor support atau persepsi dukunga supervisor dapat menjadi prediktor burnout. Dukungan supervisor didefinisikan sebagai bagaimana seorang atasan menghargai setiap kontribusi karyawan serta peduli terhadap kesejahteraannya (Bhate, 2013). Terdapat beberapa penelitian yang sejalan dengan temuan ini. Seperti penelitian oleh Blanch \& Aluja (2012) yang melaporkan bahwa persepsi yang lebih tinggi tentang dukungan supervisor dapat meredakan burnout pada karyawan di Spanyol. Ketika karyawan mendapatkan suppot dari organisasi, supervisor, dan rekan kerjanya, mereka dapat berkontribusi pada pengurangan stres terkait pekerjaan yang dialami, meningkatkan kepuasan kerja, dan meningkatkan dukungan yang dirasakan (Pandey \& Chairungruang, 2020). Sehingga, apabila karyawan yang menganggap supervisor mereka adil dan suportif, mereka kurang rentan terhadap burnout dan lebih menerima perubahan organisasi yang besar (Leiter \& Harvie, 1997; Maslach \& Leiter, 2008). Dukungan supervisor tidak hanya meredakan akibat negatif dari bekerja yang dirasakan oleh karyawan, namun juga bisa menaikkan kesejahteraan psikologis dan kemampuan bekerja karyawan (Mayo dkk., 2012; Sloan, 2012).

Penelitian bertujuan untuk mengetahui pengaruh persepsi dukungan supervisor (perceived supervisor support) dan ketakutan akan COVID-19 (fear of covid-19) terhadap job burnout pada frontline service employee (FLE) di masa pandemi COVID-19. 
Hipotesis dalam penelitian ini meliputi:

$\mathrm{H}_{1}$ : Terdapat pengaruh Perceived Supervisor Support terhadap Job Burnout pada karyawan Frontliners yang bekerja di masa pandemi Covid-19

$\mathrm{H}_{2}$ : Terdapat pengaruh Fear of Covid-19 terhadap Job Burnout pada karyawan Frontliners yang bekerja di masa pandemi Covid-19

$\mathrm{H}_{3}$ : Terdapat pengaruh Supervisor Support dan Fear of Covid-19 secara bersamaan terhadap Job Burnout pada karyawan frontliners yang bekerja di masa pandemi Covid-19

\section{Desain Penelitian}

\section{E T O D E}

Peneliti memutuskan untuk menggunakan pendekatan kuantitatif sebagai desain penelitian. Data hasil pengukuran dari pendekatan kuantitatif adalah dalam bentuk angka. Dalam pendekatan kuantitatif terdapat uji hipotesis serta proses analisa menggunakan statistik, tabel, atau diagram serta menggunakan prosedur yang terstandar (Neuman \& Djamba, 2014). Searah dengan tujuan penelitian ini yaitu guna mengetahui pengaruh perceived supervisor support dan fear of COVID-19 terhadap job burnout maka tipe penelitian yang diambil yaitu penelitian kuantitatif-eksplanatori. Penelitian kuantitatif-eksplanatori memiliki beberapa tujuan yaitu, untuk memaparkan penyamarataan sampel terhadap populasinya, menjelaskan hubungan sebuah variabel, dan menjelaskan pengaruh sebuah variabel terhadap variabel yang lain (Neuman, 2007). Tipe penlitian seperti ini dapat digunakan untuk mengukur atau menguji hubungan sebab-akibat dari dua atau lebih variabel. Terdapat beberapa teknik yang termasuk dalam metode penelitian kuantitatif, seperti survei, eksperimen, analisis konten, serta studi statistik. Berikutnya, teknik pengumpulan data menggunakan metode survei dengan media kuesioner (Neuman \& Djamba, 2014). Peneliti memilih metode tersebut karena serasi dengan tujuan penelitian, untuk menjelaskan pengaruh dan pengujian hipotesis dari suatu fenomena yang diangkat.

\section{Partisipan}

Karakteristik target populasi yaitu pekerja frontline service employee atau orang yang dalam kesehariannya bertemu secara langsung dengan customer yang bekerja ketika pandemi COVID-19 dan bukan bagian dari tenaga medis. Sedangkan, karakteristik demografis yang digunakan meliputi jenis kelamin, usia pastisipan, domisili, status perkawinan, tingkat pendidikan, dan lama bekerja. Peneliti menggunakan sampling dengan menggunakan teknik non-probability sampling, yaitu teknik dimana tidak semua komponen populasi bisa mendapatkan kesempatan untuk menjadi sampel penelitian. Teknik ini juga digunakan dikarenakan keterbatasan peneliti dalam hal uang, tenaga, dan waktu. Dalam non-probability sampling peneliti menggunakan metode accidental sampling. Pada accidental sampling, penentuan sampling bersumber pada kebetulan. Bagi siapa saja yang kebetulan sesuai dengan kriteria penelitian dan berada pada situasi, waktu, atau tempat maka dapat dijadikan sampel. Peneliti dapat memilih partisipan sesuai dengan kriteria. Peneliti menentukan jumlah sampel dengan perhitungan $G^{*}$ Power 3.1.9.6. Peneliti menggunakan A priori power analysis dengan jenis tes linear multiple regression: fixed model dan $R 2$ deviation from zero. Perhitungan ini dapat memberikan informasi tentang ukuran sampel yang dibutuhkan untuk mendeteksi effect size sebesar 0,15 dengan statistical power 95\% dan alpha 5\% dengan dua prediktor yang digunakan. Hasil hitung $G^{*}$ Power menunjukkan bahwa sampel minimum yang dibutuhkan adalah 107. Sebelumnya, partisipan mengisi lembar persetujuan atau informed consent lalu setelah itu mengisi jawaban pada ketiga alat ukur.

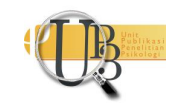




\section{Pengukuran}

Pada varibael perceived supervisor support digunakan alat ukur hasil adaptasi dari (Kottke \& Sharafinski, 1988) yang disebut sebagai Survey of Perceived Supervisor Support. Dalam alat ukur ini terdapat 16 aitem dengan 7 poin skala likert (1= "Sangat tidak setuju" hingga 7= "sangat setuju"), dengan reliabilitas sebesar 0,917. Alat ukur tersebut diadaptasi dari Survey of Perceived Organizational Support oleh (Eisenberger dkk., 1986) dengan mengganti kata "organisasi" menjadi "supervisor" pada aitem.

Alat ukur yang digunakan pada variabel fear of COVID-19 merupakan alat ukur hasil adaptasi dari penelitian oleh (Kassim dkk., 2020) yang disebut sebagai Fear of COVID-19 Scale. Terdapat 7 aitem dengan 5 poin skala likert (1= "sangat tidak setuju" hingga $5=$ "sangat setuju") dengan reliabilitas sebesar 0,838. Alat ukur tersebut diadaptasi dari alat ukur miliki Ahorsu, dkk (2020).

Pada variabel job burnout digunakan alat ukur yang diadaptasi dari penelitian oleh Purwanto (2019) dengan menggunakan teori burnout dari Maslach dkk. (2001). terdapat 22 aitem dengan 7 poin skala likert ( 0 = "Tidak pernah" hingga 6 = "Setiap Hari") pada alat ukur ini dengan reliabilitas sebesar 0,769.

\section{Analisis Data}

Tipe penelitian ini merupakan tipe penelitian kuantitatif yang akan didapatkan hasil penelitian berupa data. Sehingga perlu menggunakan analisis statistik yang berfungsi untuk mengolah data yang telah didapatkan. Peneliti memakai teknik analisis data untuk menguji pengaruh perceived supervisor support $\left(\mathrm{X}_{1}\right)$ dan fear of COVID-19 $\left(\mathrm{X}_{2}\right)$ terhadap job burnout $(\mathrm{Y})$, uji regresi dengan metode analisis regresi linear berganda. Penghitungan analisis data menggunakan program Jamovi 1.6.23 for Mac.

\section{HAS IL P E N EL I T IA N}

\section{Uji Deskriptif}

Pada penelitian ini didapatkan partisipan sebanyak 118 partisipan dengan presentase $50 \%$ laki-laki dan 50\% perempuan. Pada uji deskriptif akan ditampakkan beberapa nilai diantaranya: mean, standar deviasi, nilai minimum, dan nilai maksimum. Berdasarkan hasil uji deskriptif ditunjukkan bahwa variabel perceived supervisor support memiliki nilai $(M=86,9 ; S D=15,6$; $M i n=37$; Maks=112), variabel fear of covid-19 memiliki nilai ( $M=7,9 ; S D=5,51$; Min=7; Maks=35), dan variabel job burnout memiliki nilai $(M=63,4 ; S D=14,7 ; M i n=24 ;$ Maks=99).

\section{Uji Asumsi}

Pada penelitian ini dilakukan beberapa langkah dalam uji asumsi. Pertama, dilakukan uji normalitas agar dapat melihat sebaran data dan memastikan teknik analisis yang akan digunakan. Uji normalitas dapat menentukan apakah data dalam penelitian berdistribusi normal atau tidak (Pallant, 2011). Data dapat disebutkan normal apabila nilai skewness atau tingkat juling menjauhi +/-1 dan mendekati 0 dan nilai kurtosis dari masing-masing variabel dalam penelitian Navarro \& Foxcroft (2019). Setelah uji asumsi terpenuhi selanjutnya dilakukan uji linearitas. Uji linearitas dilakukan guna menguji bahwa terdapat hubungan linear antara varibael independen (Variabel X) dan variabel dependen (Variabel Y). pada penelitian ini peneliti menggunakan grafik scatterplots untuk melakukan uji linearitas. Berikutnya, uji multikolinearitas dilakukan untuk melihat korelasi antara dua variabel bebas yang dimiliki. Pada model regresi yang baik semestinya terbebas dari multikolinearitas dan dilihat dari besarnya nilai Tolerance $>0,1$ atau nilai VIF $<10$ (Pallant, 2011). Nilai tolerance variabel perceived supervisor support dan fear of COVID-19 sebesar (Tolerance $=0,988$ ) dan nilai VIF sebesar (VIF $=1,01)$. Sehingga, bisa

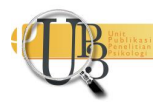


ditarik kesimpulan bahwa tidak terjadi adanya multikolinearitas pada model regresi tersebut dan kedua variabel independen tidak saling berhubungan. Selanjutnya, uji homoskedastisitas dilakukan dengan hasil jika titik-titik membentuk pola tertentu maka ada indikasi bahwa terdapat heteroskedastisitas dalam data tersebut. Namun, apabila data tidak terdapat pola tertentu maka yang terjadi adalah homoskedastisitas. Dilihat dari hasil uji, titik-titik yang dihasilkan menyebar dan tidak membentuk pola tertentu. Maka dari itu, dapat diambil kesimpulkan bahwa model regresi tersebut memenuhi asumsi homoskedastisitas.

\section{Uji Korelasi}

Selanjutnya adalah uji korelasi yang ditunjukkan dengan kekuatan dan arah hubungan antar variabel. Arah hubungan ditampakkan dengan positif atau negatif, sedangkan hubungan ditampakkan dengan angka signifikansi. Berdasarkan hasil uji korelasi diketahui bahwa perceived supervisor support berkorelasi negatif dan cenderung besar $(r(118)=-0,548 ; 95 \%$ CI $[-0,407 ;-0,663] ; p<0.001)$ dengan dengan job burnout. Sedangkan fear of covid-19 berkorelasi positif dan cenderung sedang $(r=(118)=0,269 ; 95 \%$ CI $[0,429 ; 0,093] ; p=0.003)$ dengan job burnout.

\section{Uji Regresi Linear Berganda}

Ketika uji asumsi, uji linearitas, dan uji korelasi telah terpenuhi maka langkah selanjutnya adalah multiple regression atau regresi linear berganda. Uji ini berguna untuk melihat pengaruh variabel perceived supervisor support dan fear of COVID-19 terhadap job burnout secara bersamaan atau simultan. Dihasilkan nilai $\left(F=30,2\right.$. $\left.p<0,001, \mathrm{R}^{2}=0,345\right)$. Maka dapat diambil kesimpulan bahwa persentase pengaruh perceived supervisor support dan fear of COVID-19 sebesar 34,5\% terhadap variabel job burnout. Sedangkan jika dilakukan uji regresi secara sebagian maka dihasilkan; 1) Pengaruh perceived supervisor support terhadap job burnout yaitu $\left(p=<.001\right.$ dan $\left.\mathrm{R}^{2}=-0,495\right)$. Sehingga dapat disimpulkan bahwa persentase pengaruh perceived supervisor support terhadap job burnout yaitu sebesar 49,5\%, 2) Pengaruh variabel fear of COVID-19 terhadap job burnout yaitu $\left(p=0,006\right.$ dan $\left.\mathrm{R}^{2}=0,569\right)$. Maka, dapat disimpulkan bahwa fear of COVID-19 mempunyai persentase pengaruh terhadap job burnout sebesar 56,9\%. Software Jamovi 1.6.23 for Mac digunakan untuk analisis data pada penelitian ini.

\section{I S K U S I}

Perceived supervisor support dan fear of COVID-19 secara simultan mampu mempengaruhi job burnout. Dalam penelitian ini, poengaruh yang dihasilkan yaitu sebesar 34,5\%. Hasil ini menyatakan bahwa burnout yang dialami frontline service employee atau FLE dapat diakibatkan karena tingginya ketakutan terhadap covid-19. Hal ini dapat dijelaskan dengan menggunakan Job demands-resources model (JD-R). Disini (Demerouti dkk., 2001) menyatakan bahwa burnout terjadi dalam dua proses. Pertama, job demands atau tuntutan pekerjaan, misalnya beban kerja fisik, tekanan waktu, kontak penerima, lingkungan fisik, dan kerja shift, dan situasi yang tidak aman. Kedua, kurangnya job resources/sumber daya pekerjaan, misalnya, feedback, penghargaan, kontrol pekerjaan, partisipasi, keamanan kerja, dan dukungan supervisor. Demikian pula, (Bakker \& Demerouti, 2014) menemukan bahwa, dalam model JD-R, terdapat dua proses yang beroperasi secara independen. Proses yang digerakkan oleh energi adalah "tuntutan pekerjaan $\rightarrow$ kelelahan $\rightarrow$ kinerja negatif," sedangkan proses yang didorong oleh motivasi adalah "sumber daya pekerjaan $\rightarrow$ keterlibatan $\rightarrow$ kinerja positif". Maka dari itu dapat dikatan fear of covid-19 ini merupakan job demands dan perceived supervisor support adalah job resources yang

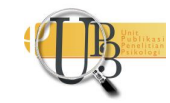


dapat mengurangi burnout pada karyawan. Supervisor yang memberikan sikap yang suportif kepada karyawan dapat membantu FLE dalam bekerja dengan baik dan tenang walaupun berada di situasi pandemi yang menakutkan bagi mereka.

Pada penelitian yang dilakukan oleh Maslach \& Leiter (2008) dikatakan bahwa perceived supervisor support dapat menjadi prediktor dari burnout. Hasilnya menerangkan bahwa perceived supervisor support dapat mempengaruhi burnout sebesar 49,5\%. Disini juga disebutkan bahwa keadilan dalam lingkungan kerja merupakan pusat teori ekuitas, yang menyatakan bahwa persepsi kesetaraan atau ketidakadilan didasarkan pada penentuan keseimbangan antara input mereka (yaitu, waktu, usaha, dan keahlian) dan output (yaitu, penghargaan dan pengakuan). Sehingga, kurangnya timbal balik antara karyawan dengan atasannya, atau proses pertukaran sosial yang tidak seimbang dalam pekerjaan dapat mengakibatkan burnout di tempat kerja. Sehingga, karyawan yang menganggap supervisor mereka adil dan suportif kurang rentan terhadap burnout dan lebih menerima perubahan organisasi yang besar (Maslach \& Leiter, 2008).

Hasil tersebut juga searah dengan penelitian-penelitian lain. Misalnya, pada studi oleh Blanch \& Aluja (2012), mereka menjumpai bahwa persepsi lebih tinggi tentang dukungan supervisor mengurangi burnout di antara karyawan di Spanyol. Dukungan dari supervisor ini juga termasuk kedalam dukungan sosial dan dukungan sosial adalah sumber daya kunci untuk mengatasi burnout (Thanacoody dkk., 2009). Supervisor dapat membantu mengurangi burnout dengan memberikan bantuan sosioemosional kepada individu dalam bentuk, misalnya, kasih sayang, pengertian, atau penghargaan dan bantuan instrumental dalam bentuk nasihat, informasi, dan bantuan dengan tanggung jawab pekerjaan.

Hasil penelitian ini juga menyatakan bahwa fear of COVID-19 memiliki pengaruh terhadap job burnout. Pengaruh yang diberikan oleh fear of COVID-19 terhadap job burnout adalah sebesar 56,9\%. Ketika FLE bekerja pada situasi yang kurang aman seperti pandemi saat ini yang dapat membuat FLE takut, maka hal ini dapat dikategorikan sebagai tuntutan pekerjaan baru yang dapat mengarah ke burnout. Pada penelitian yang dilakukan oleh Edelweiss (2021) juga dijelaskan bahwa bukan hanya beban kerja yang tinggi yang dapat memengaruhi burnout pada karyawan, namun kewajiban untuk bertemu client/customer dimasa pandemi juga menambah tingkat kekhawatiran pada karyawan bank. Hal ini, dikarenakan besarnya jumlah karyawan bank yang tertular COVID-19 melalui customer yang mereka layani (Edelweiss, 2021). Selain itu, ditemukan bahwa adanya korelasi positif antara fear of covid-19 dan associated anxiety, depresi, tingkat BOS (Burnout Syndrom) yang lebih tinggi, dan kualitas hidup yang buruk di antara frontline doctors di Mesir pada penelitian oleh pada penelitian yang dilakukan oleh (Abdelghani dkk., 2020).

\section{S I M P U L A N}

Berdasarkan analisis data yang sudah dilakukan dan hasil yang dipaparkan, maka disimpulkan bahwa ada pengaruh yang signifikan antara perceived supervisor support dan fear of COVID-19 terhadap job burnout pada frontline service employee, baik secara bersamaan atau simultan maupun parsial. Beberapa saran untuk penelitian selanjutnya yaitu, dapat dipertimbangkan waktu dalam pengambilan data karena pengambilan data pada penelitian ini dilakukan ketika angka covid-19 sudah mulai turun, penelitian selanjutnya juga dapat menelusuri lebih lanjut untuk mengetahui apakah FLE di Indonesia memang mengalami burnout saat pandemi. Pada penelitian selanjutnya juga dapat mempertimbangkan untuk mengukur burnout secara spesisik berdasarkan dimensi nya. Saran untuk supervisor adalah Job Burnout dapat berkurang apabila Supervisor memberikan sikap yang suportif. Penting untuk membuat 
Frontline Service Employee senang dan nyaman ketika bekerja karena; karyawan menjadi lebih produktif dan bahagia di tempat kerja sehingga layanan kepada customer akan menjadi lebih baik.

\section{U C A P A N T ER I MAKASIH}

Penulis mengucapkan banyak terima kasih kepada seluruh partisipan yang telah bersedia menyanggupi dan mendukung penelitian ini sehingga bisa tertuntaskan tepat waktu. Penulis berkeinginan semoga penelitian ini bisa berguna bagi frontline service employee, perusahaan, dan juga peneliti-peneliti kedepannya.

\section{DEKLARASI POTENSI TER JADINYAKONFLIK KEPENTINGAN}

Sheila Noor Maulida dan Herison Pandapotan Purba tidak bekerja, menjadi konsultan, memiliki saham, atau menerima dana dari perusahaan atau organisasi manapun yang mungkin akan mengambil untung dari diterbitkannya naskah ini.

\section{PUSTAKA ACUAN}

Abdelghani, M., El-Gohary, H. M., Fouad, E., \& Hassan, M. S. (2020). Addressing the relationship between perceived fear of COVID-19 virus infection and emergence of burnout symptoms in a sample of Egyptian physicians during COVID-19 pandemic: A cross-sectional study. Middle East Current Psychiatry, 27(1). https://doi.org/10.1186/s43045-020-00079-0

Ahorsu, D. K., Lin, C. Y., Imani, V., Saffari, M., Griffiths, M. D., \& Pakpour, A. H. (2020). The Fear of COVID19 Scale: Development and Initial Validation. International Journal of Mental Health and Addiction. https://doi.org/10.1007/s11469-020-00270-8

Bakker, A. B., \& Demerouti, E. (2014). Job Demands-Resources Theory. Wellbeing, III, 1-28. https://doi.org/10.1002/9781118539415.wbwell019

Berry, L. L., Danaher, T. S., Aksoy, L., \& Keiningham, T. L. (2020). Service Safety in the Pandemic Age. Journal of Service Research, 23(4), 391-395. https://doi.org/10.1177/1094670520944608

Berry, L. L., \& Stuart, B. (2021). An "Essential Services" Workforce for Crisis Response. Journal of Public Policy and Marketing, 40(1), 92-93. https://doi.org/10.1177/0743915620928111

Bhate, R. (2013). Supervisor Supportiveness: Global perspectives (Issue June).

Blanch, A., \& Aluja, A. (2012). Social support (family and supervisor), work-family conflict, and burnout: Sex differences. Human Relations, 611-833. https://doi.org/10.1177/0018726712440471

Chen, N., Zhou, M., Dong, X., Qu, J., Gong, F., Han, Y., Qiu, Y., Wang, J., Liu, Y., Wei, Y., Xia, J., Yu, T., Zhang, X., \& Zhang, L. (2020). Epidemiological and clinical characteristics of 99 cases of 2019 novel coronavirus pneumonia in Wuhan, China: A descriptive study. The Lancet, 395(10223), 507-513. https://doi.org/10.1016/S0140-6736(20)30211-7

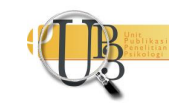


Demerouti, E., Bakker, A. B., Nachreiner, F., \& Schaufeli, W. B. (2001). The Job-Demands-Resources Model. Journal of Applied Psychology, 86(3), 499-512.

Djalante, R., Lassa, J., Setiamarga, D., Sudjatma, A., Indrawan, M., Haryanto, B., Mahfud, C., Sinapoy, M. S., Djalante, S., Rafliana, I., Gunawan, L. A., Surtiari, G. A. K., \& Warsilah, H. (2020). Review and analysis of current responses to COVID-19 in Indonesia: Period of January to March 2020. Progress in Disaster Science, 6. https://doi.org/10.1016/j.pdisas.2020.100091

Edelweiss, A. (2021). Pengaruh motivasi kerja dan self-efficacy terhadap burnout karyawan bank pada pandemi covid-19. In Repository Universitas Pelita Harapan.

Eisenberger, R., Huntington, R., Hutchison, S., \& Sowa, D. (1986). Perceived Organizational Support. Journal of Applied Psychology, 71(3), 500-507.

Greenberg, R. A. B. J. (2003). Behavior in organizations understanding and managing the human side of work. Pearson Education.

Gudi, S. K., \& Tiwari, K. K. (2020). Preparedness and lessons learned from the novel coronavirus disease. International Journal of Occupational and Environmental Medicine, 11(2), 108-112. https://doi.org/10.34172/ijoem.2020.1977

Kassim, M. A. M., Ayu, F., Kamu, A., Pang, N. T. P., Mun, H. C., Algristian, H., Sahri, M., Hambali, N. L., \& Omar, A. (2020). Indonesian Version of the Fear of COVID-19 Scale: Validity and Reliability. Borneo Epidemiology Journal, 1(2), 124-135.

Kottke, L. J., \& Sharafinski, C. E. (1988). Measuring Perceived Supervisory and Organizational Support. 1075-1079.

Leiter, M. P., \& Harvie, P. (1997). Correspondence of supervisor and subordinate perspectives during major organizational change. Journal of Occupational Health Psychology, 2(4), 343-352. https://doi.org/10.1037/1076-8998.2.4.343

Lin, C. Y. (2020). Social reaction toward the 2019 novel coronavirus (COVID-19). Social Health and Behavior, March, 2-5. https://doi.org/10.4103/SHB.SHB_11_20

Maslach, C., \& Leiter, M. P. (2008). Early Predictors of Job Burnout and Engagement. Journal of Applied Psychology, 93(3), 498-512. https://doi.org/10.1037/0021-9010.93.3.498

Maslach, C., Schaufeli, W. B., \& Leiter, M. P. (2001). Job Burnout. 397-422.

Mayo, M., Sanchez, J. I., Pastor, J. C., \& Rodriguez, A. (2012). Supervisor and coworker support: A source congruence approach to buffering role conflict and physical stressors. International Journal of Human Resource Management, 23(18), 3872-3889. https://doi.org/10.1080/09585192.2012.676930

Navarro, J. D., \& Foxcroft, D. R. (2019). Learning statistics with jamovi: A tutorial for psychology students and other beginners (Version 0.70). In Journal of Chemical Information and Modeling. 
Neuman, W. L. (2007). Basics of Social Research Methods: Qualitative and Quantitative Approaches. Allyn and Bacon.

Neuman, W. L., \& Djamba, Y. K. (2014). Social Research Methods: Qualitative and Quantitative Approaches. In Teaching Sociology (Vol. 30, Issue 3). https://doi.org/10.2307/3211488

Pallant, J. (2011). Survival Manual third edition.

Pandey, A., \& Chairungruang, S. (2020). EFFECTS OF ORGANIZATIONAL SUPPORT, SUPERVISOR SUPPORT AND COWORKERS INTERPERSONAL HELPING BEHAVIOR ON EMPLOYEE JOB SATISFACTION: A CASE STUDY IN BANGKOK, THAILAND. International Journal of Economics, Business and Accounting Research (IJEBAR), 4(2), 283-293.

Poppy. (2020, June). WFO saat Pandemi, Adakah Jaminan Kesehatannya? - Talenta.

Sainato, M. (2020). "I cry before work": US essential workers burned out amid pandemic / US news / The Guardian.

Satya, P. A. N. I. P. (2020). Covid- 19 dan Potensi Konflik Sosial. Jurnal Ilmiah Hubungan Internasional, $O(0), 39-45$. https://doi.org/10.26593/jihi.v1i1.3867.39-45

Setiati, S., \& Azwar, M. K. (2020). COVID-19 and Indonesia. Acta Medica Indonesiana, 52(1), 84.

Sloan, M. M. (2012). Unfair treatment in the workplace and worker well-being: The role of coworker support in a service work environment. In Work and Occupations (Vol. 39, Issue 1). https://doi.org/10.1177/0730888411406555

Thanacoody, P. R., Bartram, T., \& Casimir, G. (2009). The effects of burnout and supervisory social support on the relationship between work-family conflict and intention to leave: A study of Australian cancer workers. Journal of Health, Organisation and Management, 23(1), 53-69. https://doi.org/10.1108/14777260910942551

Voorhees, C. M., Fombelle, P. W., \& Bone, S. A. (2020). Don't Forget About the Frontline Employee During the COVID-19 Pandemic: Preliminary Insights and a Research Agenda on Market Shocks. Journal of Service Research, 23(4), 396-400. https://doi.org/10.1177/1094670520944606 